\section{Religion, Discourse and Power: A Contribution towards a Critical Sociology of Religion}

Critical Sociology 20I4, Vol. 40(6) 855-872 (c) The Author(s) 2013

Reprints and permissions: sagepub.co.uk/journalsPermissions.nav DOI: $10.1177 / 0896920513477664$ crs.sagepub.com

\title{
Titus Hjelm
}

University College London, UK

\begin{abstract}
This article discusses critical discourse analysis CDA) as a framework for a critical agenda in the sociology of religion. CDA uniquely brings together discursive and critical (broadly Marxist) approaches to religion, both of which have been underrepresented in current mainstream scholarship. The article argues that a CDA perspective has a lot to offer to the sociology of religion both by sensitizing scholars to the significance of discourse in creating hegemonic understandings of religion and religions in everyday social interaction dominated by the media; and by offering a framework through which to analyse the discursive construction, reproduction and transformation of inequality in the field of religion. The article discusses the concept of discourse and its different meanings, examines what being 'critical' means in the context of discourse analysis and constructs a framework for doing practical CDA. Finally, CDA is discussed as a foundation for a critical sociology of religion.
\end{abstract}

\section{Keywords}

religion, discourse, power, discourse analysis, sociology, ideology, Marxism, inequality

\section{Introduction}

If recent English-language textbooks ${ }^{1}$ are the measure, critical sociology of religion does not currently exist. 'Critical' here does not mean sociology 'hostile' to religion - although as Cadge et al. (2011) note, the field needs to be balanced in order to appreciate both the positive and negative aspects of religion - but an approach that takes the alienating power of religion seriously, and which pays serious attention to religions' contribution to social inequality. Most of the textbook wisdom trots out Marx's 150-year-old critique of religion as 'the opium of the people', reducing critique to an historical curiosity, whereas 'living' sociology of religion seems to descend almost exclusively from Durkheim and Weber. Unfortunately, that attitude also reflects much recent

\section{Corresponding author:}

Titus Hjelm, School of Slavonic and East European Studies, University College London, Gower Street, London WCIE 6BT, UK.

Email: t.hjelm@ucl.ac.uk 
scholarship. The present article charts one possible way to create a critical sociology of religion for the modern day.

I want to suggest critical discourse analysis (CDA) as a framework for a critical agenda in the sociology of religion, arguing that a CDA perspective has a lot to offer to the sociology of religion by

(1) sensitizing scholars to the significance of discourse in creating hegemonic understandings of 'religion' in everyday (mediated) social interaction, and

(2) offering a framework through which to analyse the discursive construction, reproduction and transformation of inequality in the field of religion.

CDA draws from Marxist theory, most apparently in the critique of ideology (which will be discussed at some length below). The point here is not, however, to directly tackle Marxism's or Marxist sociology's engagement - or lack thereof - with religion (for a still unsurpassed overview, see McLellan, 1987), even when I acknowledge that it is in this tradition that I think current sociology of religion can be enriched and made properly critical.

\section{Critical Sociology of Religion and the Importance of Discourse}

The starting point for a critical sociology of religion that takes discourse seriously is in two relatively recent developments in the modern world. First, although yet insufficiently studied, there are indications that the much discussed global resurgence of religion is connected with the likewise global expansion of deregulated capitalist markets. So far research has been mostly interested in the individualizing aspects of consumer societies and the consequent interest in 'spirituality' - as opposed to more institutionalized 'religion' (e.g. Heelas and Woodhead, 2005). But there are other ways of looking at the relationship in the context of the 21 st century: on the one hand, globalization and deregulation threaten tradition in general and religion in particular, a threat which creates religious opposition movements such as the Taliban and American conservative evangelicalism, to name two of the most visible examples. On the other hand, increasing global inequalities can be seen to create a 'market' for religions that provide a 'promise of salvation' (Riesebrodt, 2010) for the global underclass, in a similar (if not the same) sense as Marx envisioned when talking about the 'sigh of the oppressed creature' (Raines, 2002: 171). Despite a period when social class fell out of fashion in the social sciences, ever more obvious and increasing inequalities in the developed countries reproduce these developments on the regional, national and local levels. If ever there was a time for a critical, engaged sociology of religion, this would be it. Yet, the paradigmatic discussions (as represented by textbook knowledge) still revolve around the question of disappearance versus resurgence of religion, with little or no attention paid to religions' role in reproducing and transforming inequality. In the last section of the article, three ways will be discussed in which a critical discourse analytical approach could address this imbalance. As is clear from the above, my justification for a critical sociology of religion is a pragmatic - there are significant gaps in research - rather than a methodological one. The debate around positivist and normative sociology of religion is well covered by Goldstein (2006), for example.

The second development, the 'mediazation' of culture - the process through which our everyday knowledge becomes increasingly mediated by forms of mass communication - is a ubiquitous aspect of modern societies. Writing in 1990, John B. Thompson, who coined the term, was prescient in his analysis (Thompson, 1990). While in 1990 the media explosion was already apparent, Thompson's (and others') main concern at the time was the one-sidedness of media communication. Unlike the face-to-face situation, a response to a newspaper article only rarely becomes 
public. In the 21st century, however, previously unforeseen forms of mediated social interaction have emerged: blogs and social media abound with commentary on news from around the world, for example. Words and symbols have ceased to be the exclusive property of elites. Even if internet access is not equal globally, the ' 21 st-century citizen will work in media-, text-, and symbolsaturated environments. For the unemployed, underemployed, and employed alike, a great deal of service and information-based work, consumption, and leisure depends on their capacities to construct, control, and manipulate texts and symbols' (Luke, 1995-6: 5-6). It is therefore not an exaggeration to say that we live in an age of discourse.

The above prologue provides a backdrop or a Zeitdiagnose - a 'diagnosis of our time' (Hjelm, 2009; Mannheim, 1944) - for the context in which sociology of religion finds itself in the 21 st century. Against this backdrop it seems that

(1) there is a distinct lacuna in the field regarding critical (Marxist) approaches to religion in the modern world that take issues of domination and inequality seriously, and

(2) that it is premature to claim - somewhat fashionably - that the study of discourse is outdated.

There have been calls to abandon the study of discourse in favour of the study of practice. While I agree that ritual and non-propositional forms of practice are central to understanding religion, text and practice are not incompatible: studying discourse is not only about studying what things mean to people, but what people do when they talk about things. A discursive approach does not, therefore, contrast saying and doing; both are included. In other words, discourse analysis in the sociology of religion means looking at the ways in which religion, spirituality, belief, etc. are constructed in discourse.

This is not exactly a novel idea in some respects. James A. Beckford, perhaps most explicitly, has talked about his approach to sociology of religion as 'social constructionist' (Beckford, 2003). Approaches that explicitly employ discourse analysis are, however, far and few between. Although this might sound odd to people familiar with the work of, for example, von Stuckrad $(2003,2010)$, Brown (2009), or Wuthnow (2011), I would like to make a difference between discursive and discourse analytical approaches in the sociology of religion. In my proposed terminology, discursive approaches include what Moberg (2013) calls first- and second-level approaches that discuss metatheoretical and theoretical issues, but provide little practical advice on doing analysis - the approach that all of the abovementioned discursive studies take. Discourse analytical approaches ${ }^{2}$ focus instead on 'conducting actual discourse analyses' using empirical materials (Moberg, 2013, emphasis in the original). As will be shown below (and as Moberg notes) even 'practical' discourse analysis always includes substantial epistemological and theoretical thinking, so the boundaries are blurred. However, the above distinction does seem useful in mapping previous and future approaches to discourse analysis in the sociology of religion.

The focus of a critical approach is to examine the role of religion in creating and sustaining inequalities. So far, critical approaches in the sociology of religion have concentrated on religion's role in the constitution of racial, gender, and sexual inequalities, whereas class has played a much smaller role (McCloud, 2007). Although Marx's analysis of 19th-century social transformations cannot be applied mechanically to the 21 st century, the Marxist focus on economic power and inequality is central to CDA, both in terms of analysing discourses of class and the impact of class on discourse in capitalist society. ${ }^{3}$ This focus on class and the close interaction of discourse, power, and material conditions shares some concerns with Goldstein's (2006) worthwhile attempt at a neoMarxist 'new paradigm' of critical sociology of religion. It has, however, little to do with the 'critical theory of religion' inspired by the Frankfurt School that is at the heart of this 'new paradigm'. 
In many ways my project is restitutive rather than revolutionary in tone (despite the obvious irony). The purpose of a genuinely critical sociology of religion is not to be in awe of, say, the effects of consumerism on religion - putatively leading to a whole new understanding of religion (and sociology of religion) - but to go 'back to the basics' and critically analyse how these effects perpetuate or potentially transform inequality. Also, a 'critical agenda' does not mean abandoning the secularization thesis in favour of a 'post-secular' approach (Davie, 2007) but instead encourages the examination of how constructions of secularity and 'post-secularity' affect the social position of individuals, communities and religious traditions. CDA provides an excellent tool for this kind of analysis.

Because of the scarcity of studies employing CDA (for an excellent overview, see Moberg, 2013), my approach is suggestive rather than evaluative, that is, the focus is on how CDA could be used, rather than how it has been used. The article is divided into four main sections: First, there is a discussion of the concept of discourse and its different meanings. Second, what being 'critical' means is discussed in the context of discourse analysis. Third, a framework for doing practical CDA is constructed; and fourth, CDA is discussed as a foundation for a critical sociology of religion.

\section{Understanding Discourse}

There are as many definitions of 'discourse' as there are of 'religion', ranging from the historical 'act of conversation' to postmodern theorizations about ontology (see Engler, 2006). In one of the few analytical reviews of the use of 'discourse' in the study of religion, Engler (2006) makes a distinction between cultural studies and linguistic approaches to discourse. In Engler's schema (which is echoed by Moberg, discussed above) cultural studies approaches focus on how 'discourse shapes or constitutes the subject, in opposition to the view that language is simply a tool used by autonomous subjects' (2006: 517). He uses McCutcheon's (2003) discussion on 'Sui Generis religion' as a prime example of a Foucault-inspired cultural studies approach in the study of religion. Linguistic approaches in turn - with considerably less impact on the field - focus instead on empirical study of texts both on micro and macro levels (Engler, 2006).

The aim of CDA is to bridge these two approaches. Norman Fairclough, the main proponent of CDA (whom I will draw upon most in my own discussion), combines Foucault's ideas with what is referred to as 'functional linguistics', creating a powerful tool for the close analysis of texts (Fairclough, 1992). The theoretical underpinnings and methodological implications of CDA are crystallized in two properties that discourse is said to have: it is both constitutive and functional.

Discourse is constitutive, because it does not simply reflect or represent things 'out there', but 'constructs' or 'constitutes' them (Fairclough, 1992: 3). According to Fairclough (1992), the three things that are constituted in discourse are

(1) social identities or 'subject positions',

(2) social relationships, and

(3) systems of knowledge and belief.

These, of course, are continuously overlapping, but the distinction provides a useful analytical focus. In the sociology of religion, the 'cult controversies' provide a good example of the constitutive nature of discourse: how can it be that the same religious beliefs and practices are to some the way to salvation and to others deviant, harmful, and evil? The answer is in the different discourses that the adherents, on the one hand, and the anti-cult movement, on the other, employ. It is not that either side is consciously telling lies (although sometimes that happens as well), but rather that 
'while people may tell the truth, and nothing but the truth, it is impossible for anyone to tell the whole truth. Everyone (more or less consciously) selects what is to be included or excluded from their picture of reality according to a number of criteria - one criterion being what is relevant to their interests' (Barker, 2011: 200, emphasis in original). Although not explicitly using a discourse analytical framework, the sociology of new religious movements has been a forerunner in analysing religion (in this case 'cults') as a discursive construction (e.g. Beckford, 1985; Richardson, 1997).

Discourse has a second characteristic closely connected to Barker's observation about the interests of social actors. In addition to being constitutive, discourse is also functional (Fairclough, 1992; Potter and Wetherell, 1987: 32-33). ${ }^{4}$ Discourse itself is seen as a form of social practice, contributing both to the reproduction of society and to social change (Fairclough, 1992; Potter, 1996: 105). Edwards and Potter (1992) talk about the 'action orientation' of discourse, that is, how things are done with discourse. ${ }^{5}$ Again, the discourse of the anti-cult movement is thick with not only constructions of cults, but also descriptions of the ways cult members can be 'cured' and practical policy recommendations on how the influence of cults can be prevented. This 'cult discourse' both constructs cults as a social problem and also offers practical avenues of action to dealing with the problem (see Hjelm, 2011a).

Although the ideas of constitution and function are shared by most discourse analytical approaches, the epistemological and ontological background assumptions and, consequently, the methodological and interpretive implications vary. A crude difference could be made between approaches that see discourse as interacting with an extra-discursive social structure and those that deny or at least are indifferent towards any claims of ontological reality outside of discourse. Although discourse analysis - and the underlying epistemology of social constructionism more broadly - has often been identified only with the latter view, CDA is decidedly 'materialist' and sees discourse in dialectical interaction with broader social formations that on the one hand constrain discourse but on the other are also changed by discourse (Fairclough and Wodak, 1997). ${ }^{6}$ Although it is impossible to go into the details of the (meta-)theoretical discussion here, the latter has important methodological implications: if - as the more 'postmodern' approaches claim - the social context of discourse is continually constructed and thus cannot be independent of discourse itself, the focus is usually on smaller units of analysis, such as sequences of talk (see Wooffitt, 2006). However, if the context of discourse is seen as something independent - and stable forms of discourse practice, such as genre, suggest that this is indeed a useful view - the unit of analysis is often larger and contrasted with the broader social and cultural framework (see Fairclough, 1992; Silverman, 2007).

\section{Being Critical}

As mentioned above, Foucault and functional linguistics are two important sources of CDA. The third is Marx, or rather ideas developed by prominent Marxists such as Antonio Gramsci and Louis Althusser, although the latter features less in Fairclough's later work (Fairclough, 1989, 1992, 2003). Drawing from this critical tradition of social science, CDA focuses on 'the dynamics of power, knowledge, and ideology that surround discursive processes' (Phillips and Hardy, 2002: 20). The key terms for CDA are ideology and hegemony.

In everyday talk ideology is often understood as something akin to a worldview and has sometimes been explicitly contrasted with religion. John B. Thompson summarizes this 'grand narrative of cultural transformation' that has its sources in Marx and Weber: 'The decline of religion and magic prepared the ground for the emergence of secular belief systems or "ideologies", which serve to mobilize political action without reference to other-worldly values or beings' (Thompson, 
1990: 77). While this sense of 'ideology' is rooted in the history of the concept, CDA uses it in a different sense. The critical conception of ideology can be concisely defined as 'meaning in the service of power' (Thompson, 1990: 8; cf. Beckford, 1983). Speaking in the plural, Fairclough defines ideologies as 'constructions of reality (the physical world, social relations, social identities), which are built into various dimensions of the forms/meanings of discursive practices, and which contribute to the production, reproduction or transformation of relations of domination' (Fairclough, 1992: 87).

The contemporary discursive conception of ideology sees power as increasingly exercised through the use of persuasive language instead of coercion. When 'proper' ways of thinking about and doing things give a one-sided account that ignores the variety of practices, discourse is said to function ideologically (Chouliaraki and Fairclough, 1999: 26). For example, when the characteristics of a group of people are represented as derivable from their ethnic or religious background (e.g. 'Muslim terrorists'), the discourse 'irons out' the variety of beliefs, practices and ways of thinking in the group. Hegemony ('hegemonic discourse') is the peak of ideology, the point when all alternative constructions are suppressed in favour of one dominating view. ${ }^{7}$

The methodological implications of the critical conception of ideology are twofold: first, the focus is on how different aspects (e.g. grammar, rhetoric) of language use contribute to one-sided constructions of things or events that serve the interests of particular social groups. This is 'meaning in the service of power' in action. Furthermore, it is equally important for CDA to study what is not said, that is, what we take for granted. According to Fairclough, any reference to 'common sense' is 'substantially, though not entirely, ideological' (Fairclough, 1989: 84, emphasis in original). Because common sense naturalizes our conceptions of everyday life, it is the most effective way of sustaining hegemony, that is, an exclusive interpretation of reality. The aim of CDA is to 'unmask' the ways in which power imbalances are sustained through discourse - indeed, getting rid of 'false consciousness' (Fairclough, 1995: 17) - by drawing attention to the suppression of alternative constructions of the world. Put this way, the unmasking function of CDA could be characterized as a theory of alienation with a constructionist twist (Berger, 1973: 92; see below).

Being 'critical' does imply a normative stance, however. CDA aims at the transformation of social practice: 'CDA is unabashedly normative: any critique by definition presupposes an applied ethics' (Van Dijk, 1993: 253). But CDA is not 'standpoint theory'. Unmasking reified constructions of social reality and drawing attention to inequality are certainly at the heart of CDA and all critical social science, but as Fairclough states, CDA 'must not go beyond providing a resource for people to use in making their own decisions - it must scrupulously avoid setting out blueprints for emancipatory practice' (Fairclough, 1995: 218; cf. Richardson, 2007). While many critical discourse analysts might in practice be critical of the prevailing system of capitalist hegemony, this does not mean that CDA as such can provide the signposts for change - revolutionary or otherwise.

\section{Doing Critical Discourse Analysis}

Although all research methods have an epistemological and theoretical grounding (whether implicit or explicit), the 'theory-heaviness' of CDA can make practical analysis seem like a daunting task. Some books in the field (e.g. Fairclough, 1992, 2003; Gee, 2011) offer guidelines for analysis, but there is no mechanical way of doing CDA. Faced with an apparatus such as that offered by Fairclough in his otherwise brilliant introductory textbook (2003), a beginner could easily think that analysing a single sentence would take a year and fill a monograph. The 'secret' to coping with the bewildering potential of CDA - and what textbooks sometimes forget to mention - is that every discourse analytical study needs to be designed individually (Hjelm, 2011b). The research 
question/problem, data and method need to be aligned in a way that enables a rich, yet practically feasible analysis. Few discourse analysts concentrate on the same things in their research; rather they modify and change their analytical 'toolkit' to suit the requirements of different questions and data. With that in mind, there are, however, aspects specific to doing CDA. What makes CDA unique is the division of analysis into three different aspects that feed into each other:

(1) textual analysis,

(2) analysis of discourse practice, and

(3) analysis of social practice (for a diagrammatical representation of the three aspects, see Fairclough, 1992: 73).

Each of these is discussed below.

\section{Textual Analysis}

At the heart of CDA is the analysis of texts. 'Text' in CDA is broadly conceived and can include printed, 'found' (i.e. created independently of the researcher, see Silverman, 2007) material such as newspaper text, or 'manufactured' data such as interview transcripts. There are myriad ways of conducting text analysis (see e.g. Fairclough, 2003) ranging from the linguistic to the interpretive. This study follows John E. Richardson's (2007) version that condenses Fairclough's sometimes confusing apparatus into a workable toolkit. Also, importantly, Richardson's work also provides a glimpse into the media treatment of Islam, which I consider to be a key issue in the much discussed re-emergence of religion in the public sphere (see below).

Richardson (2007: 47) suggests that textual analysis in CDA should proceed from the microanalysis of words, through sentences onto 'larger-scale analysis of the organization of meaning across a text as a whole' (2007: 46-47). The progression is represented schematically in Table 1.

Words contextualize events and actors. Naming someone an 'insurgent' as opposed to 'freedom fighter' is the classic example of how the description of people affects our interpretation of them. Similarly, an event acquires meaning through the words used. For example, on reporting the 1991 war in Iraq, British journalists used 'destroy' and 'kill' whenever speaking of Iraqi actions, whereas US and UK troops were 'suppressing', 'eliminating' and 'neutralizing' (Richardson, 2007: 47). These (and many other contrasting word choices) create a sense of 'us' and 'them', and in this case depict the actions of western troops as mechanical dehumanized responses rather than a conscious aim to hurt an enemy. Boundary maintenance in religious movements is often done by reframing competing belief systems as evil, as in the case of the neo-Pentecostal Universal Church of the Kingdom of God, which depicts the "spiritual entities that play central, positive, healing roles in Umbanda and Candomble [syncretistic Afro-Brazilian religions] ... as "demons", (Engler, 2011: 211). Another example is naming. In a report in the Independent, a British daily newspaper, about the defeat of the Government's Terror Bill in the House of Lords, the Conservative earl of Hounslow is quoted asking: 'Why, if the home secretary thinks Mohammad el-Smith wants to do something and is planning to do something and has talked to others about doing something nasty, that is not conspiracy?' (quoted in Richardson, 2007: 50). The point the earl is making is that existing conspiracy laws would be sufficient enough to cover acts of terrorism, but it is the use of 'Mohammad el-Smith' that is interesting from a CDA perspective. The name is a combination of 'Smith', arguably the most common family name in Britain, thus the 'average man' (i.e. 'Joe Bloggs', 'John Doe'), and 'Mohammad', arguably the most common Muslim male name. The implication here is that the speaker 'believes the average terrorist suspect to be Muslim' (Richardson, 2007: 51). 
Table I. The Process of Textual Analysis in CDA (adapted from Richardson, 2007).

\begin{tabular}{ll}
\hline Micro-textual analysis & Macro-textual analysis \\
Structuring of propositions & Combining propositions \\
Words & Rhetoric \\
Transitivity & Narrative \\
Modality & \\
Presupposition & \\
\hline
\end{tabular}

Transitivity describes the processes depicted in discourse and the relationships between participants in these processes. Richardson (2007: 57) argues that the analysis of transitivity is the key to understanding representation of actions in discourse. Especially important is the masking or deletion of agency through passive sentence construction. 'Police shoot demonstrators' is an active construction, 'demonstrators are shot by the police' a passive construction. While the latter retains transitive action, the transformation can be taken further by deleting the actor completely, as in 'demonstrators are shot', a common technique in newspaper discourse especially (Fairclough, 1992: 27; Richardson, 2007: 55). Another common way of transforming agency is what Fairclough calls 'nominalization'. Here an active process is transformed into a 'state of affairs'. Thus saying 'capital is mobile' changes a transitive action ('companies move capital around the globe') into a 'state of affairs' without agency (see Richardson, 2007: 56).

The counterpart to transitivity is modality, that is, the ways in which the 'speaker or writer is committed to the claim that he or she is making' (Richardson, 2007: 59). This is very similar to what Goffman (1981) calls 'footing', referring to the 'range of relationships that speakers and writers have to the descriptions they report' (Potter, 1996: 122). Modality is usually indicated by the use of modal verbs (e.g. 'may', 'could', 'should'), their negations (e.g. 'could not', 'should not') and adverbs (e.g. 'certainly'). Categorical language (e.g. 'will', 'must', 'certainly') often appears in texts that attempt to be authoritative, but as critical discourse analysts like Fairclough and Richardson have shown, a seemingly low degree of commitment can also play a significant role in affecting our understanding of events. Richardson (2007: 60) quotes a line from the Independent (25 February 2005): 'Britain could suffer a Madrid-style terrorist attack in the run-up to the Royal Wedding and the General Election, the country's most senior police officer warned yesterday'. The 'could' actually works to heighten a sense of threat when no assessment as to what the likelihood that a terrorist attack will happen is given.

Analysing words, transitivity and modality means looking at the relationship between the form and the content (meaning) of texts. Analysing presupposition, however, means looking at the tacit assumptions made in texts. Richardson (2007: 63-64) outlines four linguistic ways presupposition is built into texts. First, certain words - such as 'stop' - presuppose certain meanings, in this case the existence of movement. Second, the definitive article ('the') and possessive articles ('his', 'her', etc.) 'trigger presuppositions.' For example, writing on 9/11, 2001, the defence correspondent of the Daily Telegraph, a British broadsheet, said, 'the Oriental tradition [...] returned in an absolutely traditional form' (quoted in Richardson, 2011:21). This presupposes an 'oriental tradition' and further, that the terrorist strike on the twin towers was representative of this tradition, even the 'true face' of the Arab/Muslim world. Third, questions such as 'why?', 'when?', and 'who?' often presuppose a state of things which is not explicit in the question itself. For example, the headline 'Why do Islamist terror groups like al-Qaeda and Hamas want to crush the West and destroy Israel?' (from the Guardian Saturday Review, 8 December 2001, quoted in Richardson, 2007: 63). This presupposes not only that Islamist terror groups do want to crush the 
West and destroy Israel, but also presupposes that both of the mentioned groups are Islamist terrorist groups and that both of these organizations want to do both of these things. Finally, noun modifiers can trigger presuppositions. As Richardson argues, modifiers are often uncontentious, but in some cases can be endowed with presupposition such as in the Daily Express (a British tabloid) headline: 'Britain's asylum system takes a new hammering' (25 February 2005, quoted in Richardson, 2007: 64). This presupposes that the asylum system has taken previous 'hammerings', a presupposition that 'fits well with the political agenda of [...] a newspaper that regularly decries what it sees as a scandalous level of "abuse" of the British asylum system' (Richardson, 2007: 64).

The above linguistic tools analyse the structuring of propositions on the level of clauses. Rhetoric and narrative organize these clauses into a coherent whole (see Table 1). Rhetoric has been an established part of philosophy, art and social science from Aristotle to today's 'new rhetoric' (Perelman and Olbrechts-Tyteca, 1999 [1969]). For the purposes of this article, suffice it to say that the aim of analysing rhetorical tropes such as metaphor and metonymy is to pay attention to the argumentative and persuasive aspects of the text. One only needs to think of the various war metaphors used in representing the alleged 'clash of civilizations' between 'the West' and the Muslim world.

Finally, in terms of text analysis, ${ }^{8}$ there is a focus on narrative. The study of narrative is, of course, a broad field in itself, but in the CDA context analysing narrative means paying attention to the sequence in which events are presented in discourse, that is, how a story unfolds. The attention to narrative is important because, as Jasinski (2001: 390) says, narratives 'establish relationships between or among things (e.g. events, states, situations) over time' (quoted in Richardson, 2007: 74). There is an important difference between narrative content (the sequence of events as they occurred) and narrative form (the sequence of events presented in discourse). The relationship between the two opens up interesting avenues of inquiry into how the truth claims of the narrative are constructed. Religion, again, is special in many ways, not least because the narrative in question takes place on a 'cosmic' scale, including 'realities other than those of everyday experience' (Berger and Luckmann, 1967: 95). Whether a narrative constructs HIV in Africa, for example, as God's divine punishment or a problem of inadequate sex education has had wide-ranging effects on policy (see Burchardt, 2011).

\section{Analysis of Discourse Practice}

As noted above, analysing discourse is always analysing language use in a particular social context. This is the domain of interpreting texts in light of broader 'social practice' (discussed below). Fairclough (1992) situates a third, middle level between texts and the social context, which he calls 'discourse practice'. This is the field of production and consumption of texts. As Phillips and Jørgensen (2002: 69) explain, to study discursive practices is to study 'how authors of texts draw on already existing discourses and genres to create a text and [...] how receivers of texts also apply available discourses and genres in the consumption and interpretation of the texts'. The most important 'mediating structures' of this kind are interdiscursivity and genre.

Interdiscursivity is Fairclough's (1992) variant of the more familiar concept of intertextuality. Intertextuality refers to "the property texts have of being full of snatches of other texts, which may be explicitly demarcated or merged in, and which the text may assimilate, contradict, ironically echo, and so forth' (Fairclough, 1992: 84). Fairclough's use of interdiscursivity emphasizes the implicit aspects of borrowing from a broader repository of discourses in addition to explicit textual references. Most obviously texts often include quotations and reported speech, which are used to support a newspaper story, for example (Richardson, 2007: 101-106). These are, however, only the manifest 
properties of interdiscursivity. In addition to borrowed texts, there is a broader borrowing from what Fairclough (following Foucault) calls 'orders of discourse': what counts as 'appropriate' talk in a classroom, or a doctor's appointment, for example, is dependent on an implicit sense of convention.

Closely related to the above notion, genre in CDA refers to 'a relatively stable set of conventions that is associated with, and partly enacts, a socially ratified type of activity, such as informal chat, buying goods in a shop, a job interview, a television documentary, a poem, or a scientific article' (Fairclough, 1992: 126). The examples Fairclough mentions are typical of social situations that are highly conventionalized. These conventions obviously have important effects on the discourse used in particular situations. Constructions of identities, relationships and beliefs in generic discourse tell us a lot about social conventions, assumptions, and expectations - and, in our case, about the role of religious discourse in particular social contexts.

\section{Analysis of Social Practice}

Although discourse is capable of both reproducing and transforming society, it would be naive to think that all discourse is equal. We can all have an opinion, but who gets to speak in public and who is listened to depend on one's structural positioning. In the case of Islam in Britain, for example, there has been a rather glaring imbalance between bureaucratic sources and Muslim respondents in newspaper discourse (Richardson, 2006). Similarly, during the early stages of the Satanism scare in Finland, the hegemonic discourse was based almost exclusively on evangelical Christian 'expertise' on the topic (Hjelm, 2008). The point is even clearer in everyday practice: in western societies, most people prefer to take medical advice from qualified professionals rather than religious leaders (although there are important exceptions to this, such as Christian Science).

Unlike the analysis of texts, the analysis of social practice is not easily adaptable into a 'toolkit'. Locke (2004: 42) summarizes the analysis of social practice as 'a focus on such things as the immediate situation that has given rise to its production and the various sociocultural practices and discursive conditions at both institutional and societal levels that provide a wider contextual relevance'. The question then is whether texts support particular types of social practice by reproducing a hegemonic agenda, or if there are 'transformative impulses' (Locke, 2004: 43) in the text. An example of this is a law proposal presented in the Finnish parliament in 2006 by two members of the Green League. The aim of the proposal was to change laws privileging the Lutheran state church (and to a lesser degree the Orthodox church) in order to make religious communities in Finland more equal. The interesting part is not necessarily the staunch opposition to the proposal by the leader of the conservative Christian Democratic Party, or by MPs with a Christian (in some cases priestly) background. More telling was the fact that out of $200 \mathrm{MPs}$, only eight took part in the discussion in the first place. The obvious opponents of the proposal did speak, but MPs from the left, for example conventionally depicted as secular - were as silent as the mainstream. The privileged position of the Lutheran Church in Finland is a deeply hegemonic social practice that is reflected in the discourse and the lack of discussion - the 'taken-for-grantedness' of the social situation.

The above example repeats the point that texts alone are not sufficient in analysing discourse. Discourse - or the absence of discourse - makes sense only within a broader social framework. The social context is analysed empirically, by looking at actors, groups and relationships within groups and between actors in society. ${ }^{9}$ In the framework of CDA, the context is also analysed theoretically, by looking at the structuration of power in a field of ideology and hegemony. It is this analysis of social practice that makes CDA distinctively different from some other approaches to discourse analysis. It is also analysis of social practice that gives CDA explanatory power: where discourse analysis has traditionally been more suitable for answering how?-questions (see Silverman and 
Gubrium, 1994), a focus on the social context enables us to argue that a line of action was one among a choice of actions that the discursive framework enabled - or alternatively, to argue how the choice of action was constrained by the social and cultural framework. In Max Weber's terms this would be something akin to a 'causally adequate' explanation (Buss, 1999; Ringer, 2002).

However, in order to make more conclusive causal claims, other types of research, such as surveys or ethnography, are needed. This is the less discussed aspect of CDA. A full-blown research project employing CDA would study the actual processes of production and consumption in addition to the textual research (cf. Fairclough, 1992: 86). The study of religion and media, for example, was for a long time interested solely in religion discourses in the media, but recent developments in research have tipped the balance towards the study of how audiences not only receive explicitly religious discourse, but also how religious discourses and identities are constructed through the use of seemingly non-religious media products (e.g. Clark, 2003).

\section{Critical Discourse Analysis in the Sociology of Religion}

Finally, I would like to discuss the relevance of CDA to several current issues in the sociology of religion and discuss topics to which a CDA approach would be especially conducive. While reflecting on broad themes instead of a detailed case study using CDA might seem like an odd strategy in light of the discursive vs. discourse analytical distinction made above, it is justified by the fact that whereas analysing constructions of religion with discourse analysis is possible from a multitude of perspectives, critical DA (and sociology of religion) has specific emphases, some of which are outlined here as an example.

In the above, news media material on Islam is often quoted, not least because for the last decade or so Islam and the alleged threat of Islam have been the main reasons for the much discussed 'return of religion' to the public sphere (see e.g. Hjelm, 2011a, 2012a; Poole and Richardson, 2006). Discussions on Islam in the modern world are also good examples of the two aspects of a critical sociology of religion that CDA would be an integral part of: the religious legitimation of social inequality; and the legitimacy of religions as a discursive construction. A CDA perspective on (de)secularization is also discussed.

\section{Opium of the People - and More}

This is no place to enter the exegetical debate on the correct interpretation of Marx's famous 'opium of the people' phrase (see Hamilton, 2001: 93; McKinnon, 2006). When Cadge et al. (2011: 442) refer to the 'excesses of old-fashioned Marxist portraits of religion as an opiate of the masses', they do not seem to have analytical sociology of religion in mind. Suffice it to say here that for Marx, religion is more than a numbing drug; it is 'a force which legitimates' the social order (Hamilton, 2001: 93-94). Although rarely considered a proponent of 'critical' sociology, and despite his ardent personal dislike of Marxism, ${ }^{10}$ Peter Berger - arguably the most influential sociologist of religion of his generation - picked up this idea (minus the class emphasis) in his widely read The Sacred Canopy (published in the UK as The Social Reality of Religion) :

[R]eligion has been the historically most widespread and effective instrumentality of legitimation. All legitimation maintains socially defined reality. Religion legitimates so effectively because it relates the precarious reality constructions of empirical societies with ultimate reality. The tenuous realities of the social world are grounded in the sacred realissimum, which by definition is beyond the contingencies of human meanings and human activity. (Berger, 1973: 41) 
Especially for the later Berger, legitimation is a matter of social cohesion (Turner, 2008: 496), but from a critical perspective, legitimation is a struggle for hegemony. In this sense religion, as expressed by Berger, is an example of ideology, or 'meaning in the service of power', as discussed above: alternative constructions of reality are suppressed by reference to an ultimate, unquestionable source - the sacred. This of course ties in with what many consider Marx's most important sociological (qua economic) contribution: the theory of alienation (Marx, 1961: 175-185, 250; see Ollman, 1976; Swain, 2012). The question for CDA is: how are these legitimations accomplished discursively? How is religious alienation reproduced and/or challenged in discourse? In this sense CDA provides a methodological source that has rarely been tapped in the sociology of religion Marxist or otherwise.

Despite processes of secularization, religious legitimations remain important in the modern world, and not just in the developing world. The obvious ones are often related to gender roles, sexuality, and reproduction. Thus we have the Catholic Church's continuing opposition to contraception, fundamentalist 'pro-life' campaigners against abortion, and completely separated spheres of life for men and women in Orthodox Jewish communities in Israel and under the Taliban rule in Afghanistan, for example. Even research that otherwise celebrates what it sees as the continuing relevance of (relatively liberal) mainstream European Christian churches (see Bäckström et al., 2011) acknowledges that the very same churches are the source of notions that have enabled the reproduction of unequal gender relationships in society (Edgardh, 2011: 63). The aim of CDA is to look at how these practices are discursively reproduced and transformed.

\section{Religion as Legitimate Identity}

One of the reasons why Fairclough has distanced himself from his earlier work is the sole emphasis on class as a difference marker. Even if Marx set the scene for analysing religion's contribution to class domination, the same domination applies to other areas of social life as well. Race, ethnicity, gender, and sexuality have all emerged as central topics of analysis during the past couple of decades. As long as secularization was accepted as the hegemonic narrative about the fate of religion in the modern world, less attention was paid to the role of religion as a difference marker. Historically, of course, religion has been the dividing issue in many contexts, but relegated to the margins of modern identity formation. That is, until at least the post-cold war awakening to a globalized world where religion still mattered. Now, of course, eminent sociologists write books about religion - without any reference to the sociology of religion - because reality seems to defy the indifference of the past 40 years or so. Secularization certainly still happens, but there is no denying that religion has re-emerged as an identity marker in the modern world.

A less discussed aspect of this re-emergence is that religion seems to be increasingly represented as a social problem (Hjelm, 2011a). While there is grand talk about 'post-secularity', and the need to acknowledge religion in the public sphere, what is at stake is the legitimacy of religion and religions in modern society. Thus, instead of looking at how religion legitimates inequality, the other side of the coin is to look at how the legitimacy of religion and religions is constructed discursively. Again, the obvious example would be Islam - with many of the examples from above pointing to the issue of legitimacy - but other, minority and alternative religions are also struggling to define themselves as legitimate all around the world. ${ }^{11}$

\section{The Discursive Dialectics of Secularization}

If there is one major 'paradigmatic' change in recent sociology of religion, it is the nearly complete abandonment of the secularization thesis in favour of 'desecularization', or even more fashionably 
'post-secularity'. While initially sceptical of 'desecularization' (Hjelm, 2012b), I have come to think that - from a CDA perspective at least - it is a preferable term to the now-hegemonic 'postsecularity' and its variants. Goldstein (2009) has usefully pointed out that the 'common sense' vision of 'old paradigm' theories of secularization as linear and inevitable is not fully justified, but that many contain dialectical elements. My aim is to complement this idea of secularization as a dialectical process with a focus on discourse.

On the one hand, a CDA approach to secularization challenges claims about the 'diminution in the social significance of religion' (Wilson, 1982: 149; cf. Bruce, 2011: 2), when those claims assume a rigid linear progress. Recent years have shown that public discourse - surely part of the 'social significance' of religion - can be desecularized in the sense that religion is back on the agenda. On the other hand, the discursive dialectics of secularization challenges 'post-secularism', when that is presented as a 'state of things': firstly, desecularization implies a process that is dialectical and reversible. There is nothing inevitable about the current prominence of religion in public discourse and prominence as such tells us little. Secondly, a CDA of the public discourse on religion in western societies can reveal that the fact that religion is back on the agenda quantitatively is not a sufficient measure for abandoning secularization as such. Quite on the contrary, it might reveal that yes, religious communities are reasserting themselves as public actors, but that their discourse is increasingly secular - a point that Bruce (2011: 171) makes in reference to the 'culture wars' in the USA. He is absolutely right in saying that '[S]ince Jürgen Habermas popularized talk of a "post-secular Europe", there has been much confusion between religion becoming more troublesome and people becoming more religious' (Bruce, 2011: 203; see Beckford, 2012).

Studies such as Wohlrab-Sahr et al. (2008) suggest that discursive conflict can also explain the subjective appropriation of a (in their case) secularized habitus. Their argument (in a nutshell) is that communicating a conflict between a scientific worldview and religion, and the incompatibility of politics and religion, had a secularizing effect on individuals in their case study of the GDR. What CDA could offer to this theory is, firstly, a methodological toolkit enabling a close analysis of how the conflict was communicated, defined, and interpreted, key terms that almost beg for methodological refinement. Secondly, conflict alone is not sufficient to explain why people appropriate particular beliefs; a theory of hegemony (see above) is needed to answer the question why people choose one of the conflicting options, not the other.

The CDA approach to secularization is, therefore, a modest approach. It provides refined tools for analysing the dynamics of public discourse on religion. However, when understood to include both text analysis and the study of production and reception of texts, it offers a powerful complement to more demographic and quantitative analyses.

\section{Conclusion}

There is justified debate about whether the world is as 'furiously religious' as ever, as Berger (1999: 2) and others have claimed, but the fact that discourse about religion is as ubiquitous as ever demonstrates that religion still matters. So, sociologists of religion still have a job to do. What has been missing (or at least very much underrepresented) in the field so far, however, has been a genuinely critical sociology of religion that looks at the role of religion in the reproduction and transformation of social inequality and domination, the ways in which religion and religions are legitimated, and the dialectical processes of public discourse and constructions of religion. Critical discourse analysis that draws from the Marxist tradition provides a powerful and yet mostly untapped source for analysing how this legitimation, reproduction or transformation is achieved. The spectre of communism may have been laid to rest for most of the world, but I am convinced that the spectre of Marx still has a lot to offer - not least for the sociology of religion. 


\section{Funding}

This research received no specific grant from any funding agency in the public, commercial or not-for-profit sectors.

\section{Acknowledgements}

I would like to thank Jim Spickard, Andrew McKinnon and Marcus Moberg for helpful comments on the first draft of this article. Any shortcomings that remain are my sole responsibility, of course.

\section{Notes}

1. Including the following works: Aldridge (2007); Davie (2007); Furseth and Repstad (2006); Hamilton (2001); McGuire (2002); Possamai (2009); Roberts and Yamane (2011). The only textbook currently on the market with a critical edge is Lundskow (2008). Also, see comments on Goldstein (2006) below.

2. Moberg uses 'discursive' and 'discourse analytic' interchangeably.

3. Interestingly, Fairclough himself has wavered between dissatisfaction with his own earlier, class-centred CDA (Fairclough, 1995: 17-18) that he thought lacked a broader focus on gender and ethnicity, and a sort of 'coming back to class' in the neoliberal 21st century (Fairclough and Graham, 2010).

4. It is important to note that this use of the term function does not refer to functionalist ideas about society - ideas which in many ways inspired constructionist critiques, which in turn have been an inspiration for discourse analysis (see Hjelm, forthcoming).

5. The same idea is also referred to as the 'performativity' of language/discourse (see Butler, 1990).

6. Chouliaraki and Fairclough (1999: 1) call this approach (following Bourdieu) alternatively 'constructivist structuralism' or 'structuralist constructivism'.

7. This, of course, is a very compact version of the discussion in Fairclough (1992). For a more detailed discussion on Laclau and Mouffe (whose work has inspired Fairclough), see Bocock (1986).

8. For alternative 'toolkits' for textual analysis see Fairclough (1992, 2003); Locke (2004); and Gee (2011).

9. Especially in terms of class analysis. See Richardson (2007); Savage (2000); Skeggs (2004).

10. Berger's move from essentially Marxist dialectics to conservatism has been discussed in Goldstein, 2009. See also Berger, 2002.

11. A detailed example of the legitimation process - and its effects - of Wicca in Finland can be found in Hjelm (2006).

\section{References}

Aldridge A (2007) Religion in the Contemporary World: A Sociological Introduction. 2nd Edition. Cambridge: Polity Press.

Bäckström A, Davie G, Edgardh N and Petterson P (eds) (2011) Welfare and Religion in 21st Century Europe, Volume 2. Aldershot: Ashgate.

Barker E (2011) The cult as a social problem. In: Hjelm T (ed.) Religion and Social Problems. New York, NY: Routledge, 198-212.

Beckford JA (1983) The restoration of 'power' to the sociology of religion. Sociological Analysis 44(1): $11-32$.

Beckford JA (1985) Cult Controversies: The Societal Response to the New Religious Movements. London: Tavistock.

Beckford JA (2003) Social Theory and Religion. Cambridge: Cambridge University Press.

Beckford JA (2012) SSSR presidential address: public religions and the postsecular: critical reflections. Journal for the Scientific Study of Religion 51(1): 1-19.

Berger PL (1973) The Social Reality of Religion. London: Penguin.

Berger PL (1999) The desecularization of the world: a global overview. In: Berger PL (ed.) The Desecularization of the World: Resurgent Religion and World Politics. Grand Rapids, MI: Eerdmans, 1-18. 
Berger PL (2002) Whatever happened to sociology? First Things 126(October): 27-29.

Berger PL and Luckmann T (1967) The Social Construction of Reality: A Treatise in the Sociology of Knowledge. Garden City, NY: Anchor Books.

Bocock R (1986) Hegemony. Chichester: Ellis Horwood.

Brown CG (2009) The Death of Christian Britain. 2nd Edition. London: Routledge.

Bruce S (2011) Secularization: In Defence of an Unfashionable Theory. Oxford: Oxford University Press.

Burchardt M (2011) Missionaries and social workers: visions of sexuality in religious discourse. In: Hjelm T (ed.) Religion and Social Problems. New York, NY \& London: Routledge, 142-156.

Buss A (1999) The concept of adequate causation and Max Weber's comparative sociology of religion. British Journal of Sociology 50(2): 317-329.

Butler J (1990) Gender Trouble. London: Routledge.

Cadge W, Levitt P and Smilde D (2011) De-centering and re-centering: rethinking concepts and methods in the sociological study of religion. Journal for the Scientific Study of Religion 50(3): 437-449.

Chouliaraki L and Fairclough N (1999) Discourse in Late Modernity. Edinburgh: Edinburgh University Press.

Clark LS (2003) From Angels to Aliens: Teenagers, the Media, and the Supernatural. Oxford: Oxford University Press.

Davie G (2007) The Sociology of Religion. London: SAGE.

Edgardh N (2011) A gendered perspective on religion and welfare in Europe. In: Bäckström A et al. (eds) Welfare and Religion in 21st Century Europe, Volume 2. Aldershot: Ashgate, 61-106.

Edwards D and Potter J (1992) Discursive Psychology. London: SAGE.

Engler S (2006) Discourse. In: von Stuckrad K (ed.) The Brill Dictionary of Religion. Leiden: Brill, 516-519. Engler S (2011) Other religions as social problem: the Universal Church of the Kingdom of God and AfroBrazilian traditions. In: Hjelm T (ed.) Religion and Social Problems. New York, NY and London: Routledge, 211-228.

Fairclough N (1989) Language and Power. London: Longman.

Fairclough N (1992) Discourse and Social Change. Cambridge: Polity Press.

Fairclough N (1995) Critical Discourse Analysis. London: Longman.

Fairclough N (2003) Analysing Discourse. London: Routledge.

Fairclough N and Graham P (2010) Marx as critical discourse analyst: the genesis of a critical method and its relevance to the critique of global capital. In: Fairclough N Critical Discourse Analysis. 2nd Edition. London: Longman, 301-346.

Fairclough N and Wodak R (1997) Critical discourse analysis: an overview. In: Van Dijk TA (ed.) Discourse Studies: A Multidisciplinary Introduction, Volume 2. London: SAGE, 67-97.

Furseth I and Repstad P (2006) An Introduction to the Sociology of Religion. Aldershot: Ashgate.

Gee JP (2011) How to Do Discourse Analysis. Abingdon: Routledge.

Goffman E (1981) Forms of Talk. Oxford: Basil Blackwell.

Goldstein WS (2006) Introduction: Marx, critical theory, and religion: a critique of rational choice. In: Goldstein WS (ed.) Marx, Critical Theory, and Religion. Chicago, IL: Haymarket Books, 1-7.

Goldstein WS (2009) Secularization patterns in the old paradigm. Sociology of Religion 70(2): 157-178.

Hamilton M (2001) The Sociology of Religion. 2nd Edition. London: Routledge.

Heelas P and Woodhead L with Seel B, Szerszynski B and Tusting K (2005) The Spiritual Revolution: Why Religion Is Giving Way to Spirituality. Oxford: Blackwell.

Hjelm T (2006) Between Satan and Harry Potter: legitimating Wicca in Finland. Journal of Contemporary Religion 21(1): 39-58.

Hjelm T (2008) Driven by the devil: popular constructions of youth Satanist careers. In: Lewis JR and Petersen J (eds) The Encyclopedic Sourcebook of Satanism. Amherst, NY: Prometheus Books, 361-380.

Hjelm T (2009) Religion in our times: Zeitdiagnose as a sociological genre. Paper presented at the Biennial Meeting of the International Society for the Sociology of Religion, 28 July, Santiago de la Compostela, Spain.

Hjelm T (2011a) Religion and social problems: three perspectives. In: Hjelm T (ed.) Religion and Social Problems. New York, NY and London: Routledge, 1-11. 
Hjelm T (2011b) Discourse analysis. In: Engler S and Stausberg M (eds) The Routledge Handbook of Research Methods in the Study of Religion. London: Routledge, 134-150.

Hjelm T (2012a) Introduction: Islam and Muslims in European news media. Journal of Religion in Europe 5(2): $137-139$.

Hjelm T (2012b) Desecularization. In: Juergensmeyer M and Roof WC (eds) Encyclopedia of Global Religion. Thousand Oaks, CA: SAGE, 292-294.

Hjelm T (forthcoming) Perspectives on Social Constructionism. Basingstoke: Palgrave.

Jasinski J (2001) Sourcebook on Rhetoric: Key Concepts in Contemporary Rhetorical Studies. Thousand Oaks, CA: SAGE.

Locke T (2004) Critical Discourse Analysis. London: Continuum.

Luke A (1995-6) Text and discourse in education: an introduction to critical discourse analysis. Review of Research in Education 21: 3-48.

Lundskow G (2008) The Sociology of Religion: A Substantive and Transdisciplinary Approach. Thousand Oaks, CA: Pine Forge Press.

McCloud S (2007) Divine Hierarchies: Class in American Religion and Religious Studies. Chapel Hill, NC: University of North Carolina Press.

McCutcheon RT (2003) Manufacturing Religion: The Discourse on Sui Generis Religion and the Politics of Nostalgia. Oxford: Oxford University Press.

McGuire M (2002) Religion: The Social Context. 5th Edition. Long Grove, IL: Waveland Press.

McKinnon AM (2006) Opium as dialectics of religion: metaphor, expression and protest. In: Goldstein WS (ed.) Marx, Critical Theory, and Religion. Chicago, IL: Haymarket Books, 11-29.

McLellan D (1987) Marxism and Religion. Basingstoke: Macmillan.

Mannheim K (1944) Diagnosis of Our Time. New York, NY: Oxford University Press.

Marx K (1961) Selected Writings in Sociology and Social Philosophy. Edited by T.B. Bottomore and M. Rubel. Harmondsworth: Penguin.

Moberg M (2013) First-, second-, and third-level discourse analytic approaches in the study of religion: moving from meta-theoretical reflection to implementation in practice. Religion 43(1): 1-22.

Ollman B (1976) Alienation: Marx's Conception of Man in Capitalist Society. 2nd Edition. Cambridge: Cambridge University Press.

Perelman C and Olbrechts-Tyteca L (1991 [1969]) The New Rhetoric: A Treatise on Argumentation. Notre Dame, IN: University of Notre Dame Press.

Phillips L and Jørgensen MW (2002) Discourse Analysis as Theory and Method. London: SAGE.

Phillips N and Hardy C (2002) Discourse Analysis: Investigating Processes of Social Construction. Sage University Papers Series on Qualitative Research Methods, 50. Thousand Oaks, CA: SAGE.

Poole E and Richardson J (eds) (2006) Muslims and the News Media. London: I.B. Tauris.

Possamai A (2009) Sociology of Religion for Generations $X$ and $Y$. London: Equinox.

Potter J (1996) Representing Reality: Discourse, Rhetoric, and Social Construction. London: SAGE.

Potter J and Wetherell M (1987) Discourse and Social Psychology: Beyond Attitudes and Behaviour. London: SAGE.

Raines J (ed.) (2002) Marx on Religion. Philadelphia, PA: Temple University Press.

Richardson JE (2006) Who gets to speak? A study of sources in the broadsheet press. In: Poole E and Richardson JE (eds) Muslims and the News Media. London: I.B. Tauris, 103-115.

Richardson JE (2007) Analysing Newspapers: An Approach from Critical Discourse Analysis. Basingstoke: Palgrave.

Richardson JT (1997) The social construction of Satanism: understanding an international social problem. Australian Journal of Social Issues 32(1): 61-85.

Richardson R (2011) Big pictures and daily details: the content and form of narratives. In: Petley J and Richardson R (eds) Pointing the Finger: Islam and Muslims in the British Media. Oxford: Oneworld Publications, 21-39.

Riesebrodt M (2010) The Promise of Salvation: A Theory of Religion. Chicago, IL: Chicago University Press. 
Ringer F (2002) Max Weber and causal analysis, interpretation and comparison. History and Theory 41(2): 163-178.

Roberts KA and Yamane D (2011) Religion in Sociological Perspective. 5th Edition. Thousand Oaks, CA: Pine Forge Press.

Savage M (2000) Class Analysis and Social Transformation. Buckingham: Open University Press.

Silverman D (2007) A Very Short, Fairly Interesting and Reasonably Cheap Book about Qualitative Research. London: SAGE.

Silverman D and Gubrium JF (1994) Competing strategies for analyzing the contexts of social interaction. Sociological Inquiry 64(2): 179-198.

Skeggs B (2004) Class, Self, Culture. London: Routledge.

Swain D (2012) Alienation: An Introduction to Marx's Theory. London: Bookmarks.

Thompson JB (1990) Ideology and Modern Culture. Stanford, CA: Stanford University Press.

Turner BS (2008) The constructed body. In: Holstein JA and Gubrium JF (eds) Handbook of Constructionist Research. New York, NY: The Guilford Press, 493-510.

Van Dijk TA (1993) Principles of critical discourse analysis. Discourse and Society 4(2): 249-283.

von Stuckrad K (2003) Discursive study of religion: from states of the mind to communication and action. Method and Theory in the Study of Religion 15(3): 255-271.

von Stuckrad K (2010) Reflections on the limits of reflection: an invitation to the discursive study of religion. Method and Theory in the Study of Religion 22(2/3): 156-169.

Wilson B (1982) Religion in Sociological Perspective. Oxford: Oxford University Press.

Wohlrab-Sahr M, Schmidt-Lux T and Karstein U (2008) Secularization as conflict. Social Compass 55(2): $127-139$.

Wooffitt R (2006) The Language of Mediums and Psychics: The Social Organization of Everyday Miracles. Aldershot: Ashgate.

Wuthnow R (2011) Taking talk seriously: religious discourse as social practice. Journal for the Scientific Study of Religion 50(1): 1-21. 
Downloaded from crs.sagepub.com at University College London on July 28, 2015 